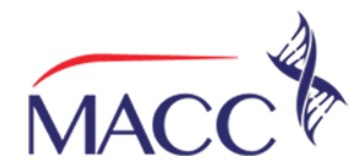

\title{
Intubasi dengan Menggunakan Laringoskop McCoy dan Macintosh
}

\author{
Andriamuri Primaputra Lubis
}

Editor Majalah Anestesia \& Critical Care

Tindakan intubasi endotrakeal memiliki tingkat kesuksesan yang sangat tinggipada pasien-pasien yang akan dilakukan tindakan anestesi secara elektif. Sedangkan pada kasus-kasus emergensi ataupun kasus-kasus sulit intubasi, tindakan intubasi endotrakeal menjadi tantangan dan membuka perspektif yang berbeda. ${ }^{1}$ Laringoskop merupakan suatu instrumen yang digunakan untuk memeriksa regio laring dan memfasilitasi tindakan intubasi endotrakea.

Laringoskop terdiri atas bagian handle berisi baterai yang memberi daya bola lampu dan bagian blade. ${ }^{2}$ Tujuan dari laringoskop adalah untuk mendapatkan visualisasi baik daripada pita suara untuk menghasilkan intubasi endotrakeal yang baik. Laringoskop direk sangat tergantung pada ekstensi kepala pada bagian sendi atlantooccipital dan fleksi dari bagian bawah cervicalspine untuk mendapatkan aksis mulut, faring dan laring. ${ }^{3}$

Di lain pihak, laringoskopi dan intubasi endotrakeal merangsang respons stres hemodinamik, salah satunya dengan merangsang peningkatan katekolamin yang berujung pada keadaan takikardi dan hipertensi, namun dapat juga menstimulasi vagal yang berujung pada aktivasi sistem parasimpatis yang bermanifestasi pada kondisi bradikardia dan hipotensi dimana kondisi tersebut membahayakan bagi pasienpasien dengan penyakit jantung iskemik ataupun hipertensi. Gejolak hemodinamik saat dilakukannya tindakan intubasi endotrakeal sebaiknya ditekan untuk menyeimbangkan antara suplai dan kebutuhan oksigen miokardiak, dimana hal tersebut adalah kunci untuk melakukan intubasi pada anestesi. ${ }^{4}$

Perlu diketahui terdapat berbagai macam komplikasi dari tindakan intubasi endotrakeal pada kondisi emergensi, antara lain cardiac arrest, hipotensi, hipoksemia, regurgitasi, dan beberapa komplikasi kecil lainnya, misalnya intubasi bronkial, trauma gigi dan bibir, trauma jalan nafas dan reaksi alergi. Penelitian menunjukkan $97 \%$ pasien yang diintubasi mengalami komplikasi tindakan, seperti intubasi masuk ke esofagus (5\%), trauma gigi dan bibir (4\%), regurgitasi (2\%) dan hipotensi (2\%). ${ }^{1}$

Blade yang digunakan untuk laringoskopi seharusnya juga hanya menimbulkan minimal respons stres pada pasien, namun di sisi lain blade laringoskop juga harus mampu memfasilitasi tampilan intubasi yang baik sehingga tindakan intubasi endotrakeal yang mulus dapat dilakukan. ${ }^{4}$

Terdapat berbagai macam blade laringoskop yang biasa digunakan dalam praktik anestesi sehari-hari, antara lain Macintosh, Miller, Wisconsin, laringoskop McGrath, hingga McCoy. ${ }^{2}$ Laringoskop didesain oleh Macintosh pada tahun 1943 adalah jenis laringoskop yang paling berhasil dan bertahan lama dalam era praktik anestesi. ${ }^{5}$ Laringoskop Macintosh adalah jenis laringoskop yang paling dikenal dan banyak digunakan, tingkat kesuksesan tinggi, dan penggunaannya juga relatif mudah dipelajari. Kekurangan laringoskop blade Macintosh adalah lengkungannya yang dapat menutup visualisasi glotis dan jalur intubasi pada kondisi jalan napas 
sulit. Dasar lidah juga dapat tertekan ke arah distal dan terjadi penekanan paksa pada epiglotis dan valekula ke atas, serta terjadi pergeseran epiglotis ke arah posterior untuk visualisasi pita suara pada saat laringoskopi intubasi. Manuver ini menimbulkan respons lonjakan hemodinamik yang lebih besar dibanding dengan McCoy. ${ }^{6}$ Blade McCoy sendiri merupakan modifikasi daripada blade Macintosh. McCoy pertama sekali di perkenalkan pada tahun 1993. Ujung dari McCoy merupakan ujung berengsel dan ketika blade dimasukkan ke valekula, bagian ujungnya bekerja pada ligamentum hyoepiglottic dan mengangkat epiglottis untuk mengekspos tampilan glottis lebih baik dengan pergerakan leher yang lebih sedikit. ${ }^{7}$ McCoy lebih ramping daripada Macintosh baik pada bagian blade (1,6 cm Macintosh dan 1,2 cm untuk McCoy) maupun handle $(2,2 \mathrm{~cm}$ Macintosh dan $1,5 \mathrm{~cm}$ untuk McCoy). ${ }^{8}$

Berbagai macam penelitian dilakukan di beberapa negara untuk menilai penggunaan blade laringoskop, termasuk diantaranya untuk menilai tanggapan kardiovaskular dan kemudahan tindakan intubasi. Penelitian menyebutkan bahwa respons hemodinamik terhadap laringoskop dikatakan signifikan jika terjadi peningkatan parameter seperti denyut nadi, tekanan darah sistolik, tekanan darah diastolik dan tekanan darah rata-rata lebih dari $20 \%$ di atas baseline. ${ }^{4}$

Suatu penelitian oleh Kanase pada tahun 2019 menyebutkan bahwa blade McCoy menunjukkan peningkatan respons hemodinamik lebih rendah, visualisasi glottis yang lebih baik, dan tindakan intubasi yang lebih mulus. Blade McCoy menunjukkan hemodinamik respons yang lebih minimal jika dibandingkan dengan blade Macintosh. ${ }^{4}$ Penelitian berbeda dilakukan di India pada tahun 2021, didapati bahwa penggunaan blade McCoy dan blade Macintosh menghasilkan gejolak hemodinamik yang relatif sama pada tindakan intubasi endotrakea, namun dikatakan pada penelitian ini dijumpai kelemahan berupa adanya perbedaan kriteria inklusi pada sampel penelitian dibandingkan penelitian lain, limitasi lainnya berupa ditemukannya kesulitan dalam teknik blinding pada penelitian yang menyebabkan tingginya kemungkinan potensi bias dalam penelitian. ${ }^{9}$
Di Indonesia, penelitian serupa pernah dilakukan pada penduduk dengan ras Melayu. Pada penelitian tersebut didapatkan persentase peningkatan laju nadi dan peningkatan MAP lebih tinggi pada kelompok Macintosh dibandingkan McCoy. Blade McCoy efektif mencegah gangguan hemodinamik saat instrumentasi. Keadaan ini terjadi karena kontak minimal dengan jalan nafas saat laringoskopi. ${ }^{6}$

Penelitian serupa dilakukan oleh residen anestesi di Universitas Airlangga, Indonesia. Penelitian tersebut menidapatkan bahwa penggunaan blade McCoy lebih efektif dibandingkan dengan penggunaan blade Macintosh dengan didapatkannya perbedaan yang bermakna. Blade McCoy dikatakan dapat memberikan tampilan laryngeal yang lebih baik, fluktuasi hemodinamik yang lebih rendah (penilaian tekanan darah dan denyut jantung), skala nyeri (qNOx), serta minimal nyeri tenggorokan pascaoperasi. ${ }^{10}$

\section{REFERENCES}

1. Lestari MI. Video Laryngoscope: To Be or Not (Yet) To Be Used?. MajAnestCriCare Vol. 39 No.2

2. Butterworth JF, Washnick JD, Mackey DC. Morgan \& mikhail's clinical anesthesiology. 5th ed. New York: Mc Graw Hill; 2013.

3. Kanase NV, Gandhi S, Todi SR. Ease of Intubation While Using Macintosh a Type) Laryngoscope Blade Undergoing with Anaesthesiology. European Journal of Molecular \& Clinical Medicine; 2020; 7(1): 70-3

4. Kanase NV, Gandhi S, Todi SR. Comparison between macintosh and levering (mccoy's type) laryngoscope blade to study stress response and ease of intubation. International journal of scientific research; 2019; (3):62-6

5. Choudhary VK, et al. Comparison of hemodynamic responses along with perfusion index to tracheal intubation with Macintosh and McCoy laryngoscopes. Int J Res Med Sci; 2018; 6(5):1673-1681

6. Hutariyus A., Fuadi I., Bisri DY. Perbandingan Peningkatan Laju Nadi dan MAP antara Laringoskopi Menggunakan Bilah Laringoskop Macintosh dan McCoy. JAP; 
2019;7(1):1-9.

7. Bharti N, Arora S, Panda NB. A comparison of McCoy, TruView, and Macintosh laryngoscopes for tracheal intubation in patients with immobilized cervical spine. Saudi Journal of Anesthesia;2014;8(2): 18892

8. Bansal T, Taxak S, Yadav A, Singh S. McCoy Laryngoscope: A savior in patient with limited mouth opening. J Anaesthesiol Clin Pharmacol; 2019;35:406-7.

9. Buhari FS, Selvaraj V. Randomized controlled study comparing the hemodynamic response to laryngoscopy and endotracheal intubation with McCoy, Macintosh, and C-MAC laryngoscopes in adult patients. Journal of Anaesthesiology Clinical Pharmacology; 2016;2(4):505-9

10. Lorena C., Salinding A., Airlangga SP. Effectiveness Comparison Of Using MACINTOSH Blade And McCoy Blade For Endotracheal Intubation In Anesthesia Residents. IJAR; 2021;3(2):46-53 